\title{
The vitamin A potency of fish liver oil and its effect on the growth of albino rat
}

\author{
Haruo Baba
}

(The National Institute of Nutrition)

\begin{abstract}
As shown in the previous report, the bio-potencies of fish and whale liver oils were different depending on the materials; some of them had the high potencies almost comparable to that of all-trans vitamin $\mathrm{A}$, but some had only $70 \%$ in relative bio-potency. This difference is considered to be due to the isomerisation occured under the various conditions by the estimation from their maleic values, and such a difference was also observed in the synthetic vitamin A. Although same result was also observed in the bio-test, but there was a trend to cause difference in the growth response depnding on the dose. The experimental value previously reported in this country was obtained at the relatively high level of vitamin A and it did not show any difference between the synthetic $A$ and the natural $A$, so it is necessary to consider that the feeding effect of fish liver oil expected as the growth effect is different from the vitamin A potency and it is also necessary to compare the vitamin A potencies on the feeding level.
\end{abstract}

In this report, the bio-potencies are estimated from the maleic values of several fish liver oils by the method already described in the previous report and the results are confirmed by the growth test of albino rats same as in the previous report. Then I compared their vitamin A potencies at the feeding level by changing the dose and the feeding method of vitamin A.

The estimation of bio-potency is obtained from the relationship between the vitamin A potency obtained by the liver storage bioassay and the maleic value, this method is applied in this experiment to confirm the values.

Finally, I compared the values in this and in the previous reports with the values of vitamin A potency obtained by the various determinations.

The followings are the experimental methods, results and discussions.

\section{Experiment I}

Methods : the albino rats growth test of vitamin A and the determination of maleic values of fish liver oils are already described in the previous report.

Results : the weight increases of each group per week obtained from the curves in Fig. 1 are shown in Table 1 and the relative bio-potency calcurated from these values are $80 \%$ of that of all-trans vitamin A. 
102 The vitamin A potency of fish liver oil and its effect on the growth of albino rat 第 20 巻

Fig. 1. The growth curves of the vitamin A defficient albino rats fed the critical dose of vitamin A.

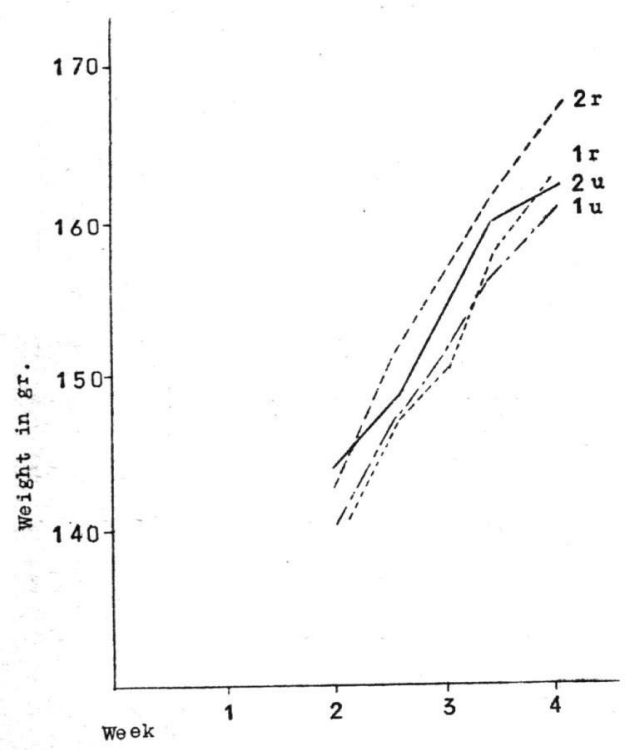

Note: Each group contains 10 animals. Daily vitamin A doses are 1 I. U. and 2 I. U. per head, perday.

Fig. 2. The growth curves of young albino rats

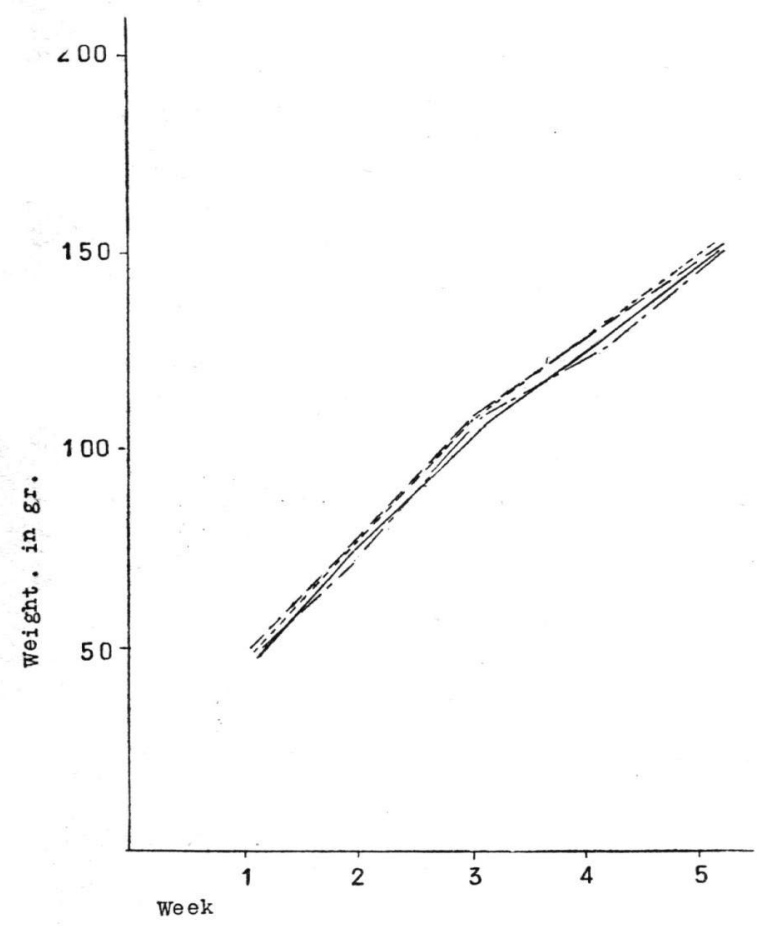

Note: Vitamin A level is same as in Fig. 1.
Table 1. The weight increase and the estimated relative bio-potency for the vitamin A deficient albino rat.

\begin{tabular}{lccc}
\multicolumn{1}{c}{ Group } & $\begin{array}{c}\text { Total } \\
\text { weight increase } \\
\text { g./week }\end{array}$ & $\begin{array}{c}\text { Estimated } \\
\text { relative } \\
\text { bio-potency }\end{array}$ \\
Synthetic vitamin A & $1 \mathrm{r}$ & 99.9 & $100 \%$ \\
palmitate & $2 \mathrm{r}$ & 133.3 & \\
Natural vitamin A & $1 \mathrm{u}$ & 104.7 & 72 \\
(fish liver oil) & $2 \mathrm{u}$ & 121.4 & \\
\multicolumn{4}{c}{ Resulted relative bio-potency } \\
\multicolumn{4}{c}{$80 \%$}
\end{tabular}

\section{Experiment II}

The result in he Experiment $I$ is same as that in the previous report and the value is a little higher than the bio-potency estimated from the maleic value but it is different from that of all-trans vitamin A. But the growth curves for the weaning male rats of same strain without any vitamin $A$ deficient period shown in Fig. 2 do not cause any difference for more than five weeks at the same level of vitamin dose between them.

\section{Experiment III}

The growth of rats fed $10 \mathrm{I}$. U. and $20 \mathrm{I}$. U. of vitamin A per head per day is observed by the method used in the Experiment II. These doses correspond to about $1000 \mathrm{I}$. U. per $\mathrm{Kg}$ of feed which is nearly feeding level per body weight of the animal or a little lower. As described before, the growth potency should be expected as a feed and is different from true vitamin A potency. So the difference as the vitamin A source between the fish liver oil and the synthetic vitamin A should be considered that obtained 
by the dose of feeding level. I compared these values. The vitamin A doses for fish liver oil group and synthetic A group are estimated by their maleic values, and vitamin A level of the synthetic vitamin A group is limitted to about $70 \%$ of that of the natural vitamin A group : the same growth effect is expected at these levels.

The experimental result shown in Fig. 3 shows that fish liver vitamin A group has a better growth effect.

The apparent vitamin A potency of the fish liver oil calculated from the average weight increase per week is $126 \%$ and it is clearly higher than that of the synthetic vitamin A.

\section{Experiment IV}

The values obtained from the growth experiment have the same trend as those estimated by the maleic values but the former is a little higher than the latter in the natural vitamin A. The growth experiment is used here for the determination of vitamin A bio-potency and for the comparison of the synthetic vitamin A oil with the natural vitamin A oil because the growth experiment has been used for these purposes in this country But, as the equation for the estimation of vitamin A bio-potency by the maleic value is derived from the relationship between the maleic value and the bio-potency of vitamin A obtained from the liver storage bioassay, the liver storage bioassay of vitamin A using several fish liver oils is carried out here to confirm this relationship.

Samples : molecular distilled fish liver oils (107,000 I. U. and 109,000 I. U.). Their relative bio-potencies estimated from the maleic values obtain $\epsilon$ d by the method already described in the previous paper are both $74 \%$.

Method: although many methods were already presented for the liver storage bioassay, the 4) method of Embree et al is used here.

Results: All the values obtained by this method were a little higher than those estimated from thier maleic values. The results are shown in Fig. 4 where the vertical axis indicates the relative bio-potency and the horizontal axis indicates the maleic value. The equation 
104 The vitamin A potency of fish liver oil and its effect on the growth of albino rat 第 20 巻

Fig. 4. The relationship between the maleic value and the relative biopotency (A comparison with the result of Ames)

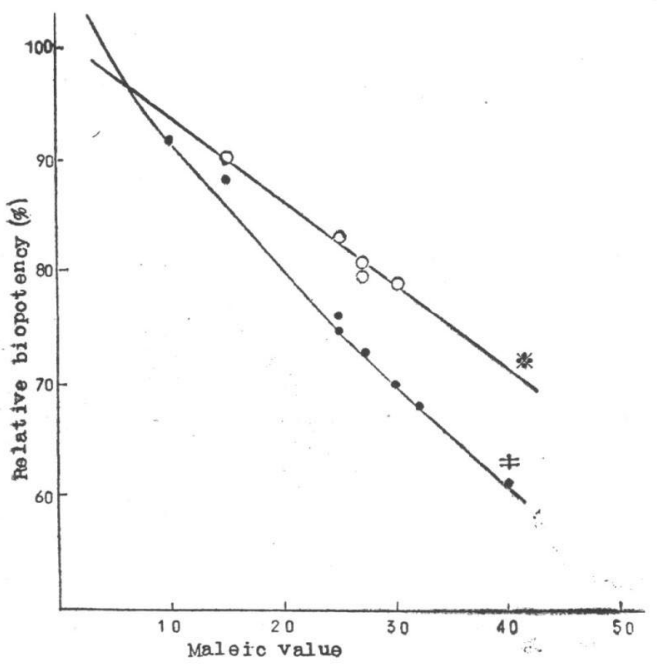

*(\%) $\mathrm{RP}=101.6-\mathrm{MV} \times 0.7647(\mathrm{BABA})$

$\neq \mathrm{RP}=99.5-0.2(\mathrm{MV})^{2}+0.000768(\mathrm{MV})^{3}$

(AMES)

under Fig. 4 was obtained from the curve by the simplification and the correction using the method of least squares.
Table 2. The amounts of vitamin $\mathrm{A}$ in liver and the relative bio-potencies estimated from the maleic values (1)

$\begin{array}{lccc}\text { Group } & & \begin{array}{c}\text { Vitamin A } \\ \text { in liver }\end{array} & \begin{array}{c}\text { Estimated } \\ \text { relative } \\ \text { bio-potency }\end{array} \\ \text { Synthetic } & 1 \mathrm{r} & 482 \text { I. U. } & 97 \% \\ \text { vitamin A } & 2 \mathrm{r} & 1,248 & \\ \text { Natural } & 1 \mathrm{u} & 397 & 74 \\ \text { vitamin A } & 2 \mathrm{u} & 1,013 & \end{array}$

- $\quad$ Resulted relative bio-potency $82.7 \%$

Notes: Each group contains 10 albino rats.

Daily dose per head 500 I. U. . .1000 I. U. Total dose per head 1500 I. U. . .3000 I. U.

Table 3. The amounts of vitamin $\mathrm{A}$ in liver and the relative bio-potency estimated from the maleic values (2)

Group $\begin{array}{cc}\text { Vitamin A } \\ \text { in liver }\end{array} \begin{gathered}\text { Estimated } \\ \text { relative } \\ \text { bio-potency }\end{gathered}$

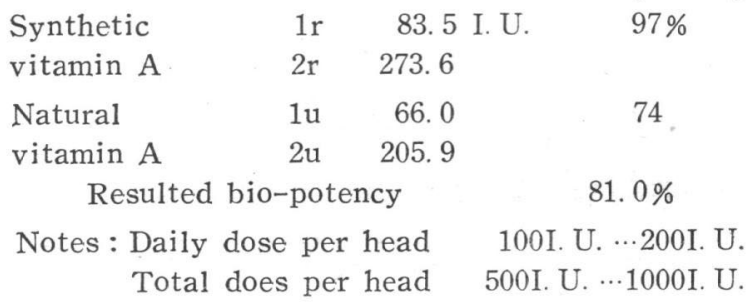

\section{A comparison of fish liver oil vitamin A potencies obtained by various determina-}

\section{tions}

As shown above in the bio-tests, the relative bio-potency of vitamin A was a little higher than that estimated by the maleic value. And the vitamin A potency of fish liver oil is shown in the relative bio-potency expressed in percentage of the bio-potency of all-trans vitamin A,

Table 4. The vitamin A potencies of fish liver oils

\begin{tabular}{|c|c|c|c|c|c|}
\hline \multirow[b]{2}{*}{ Materials } & \multirow[b]{2}{*}{$\begin{array}{l}\text { Spectro- } \\
\text { photometry } \\
\text { I. U. /g }\end{array}$} & \multirow{2}{*}{$\begin{array}{l}\text { Carr, } \\
\text { Price } \\
\text { Method } \\
\text { I. U. /g }\end{array}$} & \multicolumn{3}{|c|}{ Relative bio-potency (\%) } \\
\hline & & & $\begin{array}{l}\text { Growth } \\
\text { method }\end{array}$ & $\begin{array}{l}\text { Liver } \\
\text { storage } \\
\text { method }\end{array}$ & $\begin{array}{l}\text { MV } \\
\text { method }\end{array}$ \\
\hline
\end{tabular}

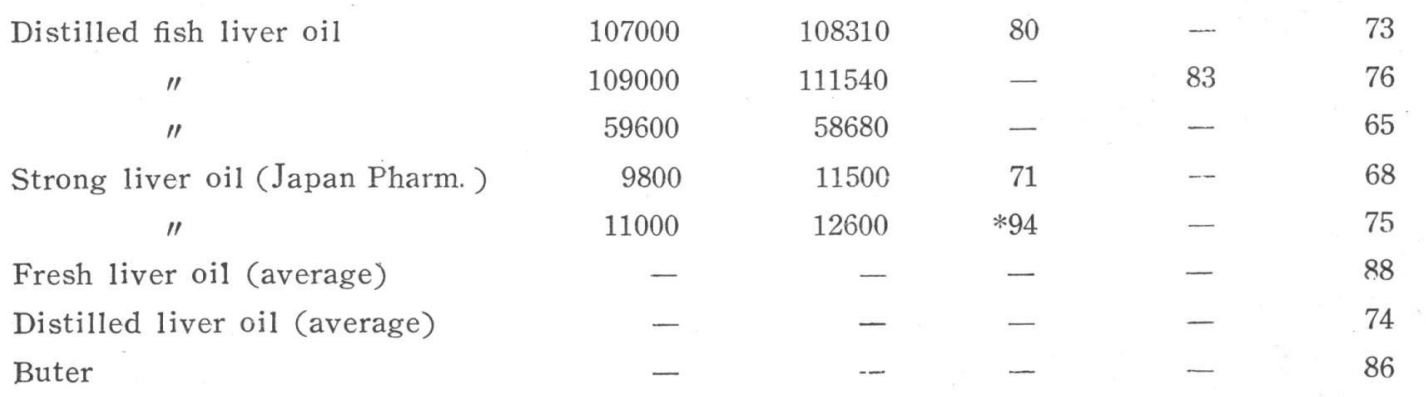


Table 5. The comparison of fish liver oil vitamin A values by various determinations

\begin{tabular}{cccccc}
\multicolumn{5}{c}{ (I. U. /g) } \\
Sample & U. S. P. 16 & C. P. & M. V. & R. P. (\%) & M. V. /U.S. P. (\%) \\
1 & 111,000 & 120,640 & 89,280 & 74 & 80 \\
2 & 217,000 & 242,600 & 169,800 & 70 & 78 \\
3 & 111,000 & 127,220 & 91,400 & 78 & 82 \\
4 & 223,000 & 313,400 & 200,560 & 64 & 90 \\
5 & 430,000 & 479,745 & 374,200 & 78 & 87 \\
6 & 136,100 & 151,180 & 139,000 & 92 & 102
\end{tabular}

Table 6. The comparison of vitamin A potencies estimated from the maleic values by the corrected equation with $\Delta$ those obtained by the original method

$\begin{array}{cccccc}\text { Sample } & \begin{array}{c}\text { U.S. P. } 16 \\ \text { I. U. } / g\end{array} & \Delta \text { R. P. (\%) } & \begin{array}{c}\text { Corrected } \\ \text { R.P. }(\%)\end{array} & \begin{array}{r}\Delta \text { Vitamin A } \\ \text { Value by M. V. } \\ \text { I. U. }\end{array} & \begin{array}{c}\text { Corrected } \\ \text { V. A. value } \\ \text { I. U. }\end{array} \\ 1 & 111,000 & 74 & 83 & 89,280 & 100,000 \\ 2 & 217,000 & 70 & 79 & 169,800 & 192,000 \\ 3 & 111,000 & 78 & 85 & 91,400 & 99,800 \\ 4 & 223,000 & 64 & 74 & 200,560 & 231,000 \\ 5 & 430,000 & 78 & 85 & 374,200 & 408,000 \\ 6 & 136,100 & 92 & 94 & 139,000 & 142,000\end{array}$

we must know this value comparing with those obtained by the spectrophotometries, such as the method in the 16 th edition of U.S. Pharmacopeia, frequently used now in the commercial transactions. The results of the comparison of the values obtained by the bio-tests, spectrophotometry and antimony trichloride method including the values in the previous paper are shown in Table 4 and Table 5.

Table 6 is the comparison of the values calculated by the equation to obtain the relative bio-potency from the maleic value simplified and corrected by the results of author's bio-tests. with those calculated by the Ames' original equation.

\section{Discussion}

In the previous report, the relative bio-potencies of fish liver oil vitaminA estimated by maleic value using the Ames' method were about $70 \sim 90 \%$. It was discussed there that this difference is due to the isomerisation of vitamin $\mathrm{A}$ in fish liver oil and that the vitamin $\mathrm{A}$ of fish liver oil is not always inferior to the synthetic vitamin A for some fish liver oil samples showed the same potencies as all-trans vitamin A. The difference in the growth effect by the level of the dose was also observed. In this report, the growth and the liver storage experiments of albino rats were performed to confirm the relationship between the maleic value and the vitamin A potency. The values obtained in these bio-tests were a little higher than those by the Ames' original method. The simplification and the correction of the estimation equation using these results were tried. The estimated vitamin A value re-calculated 

by the gained equation was about $10 \%$ higher than that in the previous reports in the relative bio-potency. The growth effect of fish liver oil on the feeding level of vitamin A was about $25 \%$ higher than that of the synthetic vitamin A oil.

As the true response to the growth is considered to be limitted in a small range of the dose the potency obtained here may be apparent, but this result is interesting because the vitamin A potency as a feed is the growth effect expected at the feeding of the sufficient dose.

The potency of fish liver oil vitamin $A$ is expressed as the percentage of that of the synthetic vitamin A when all the vitamin A in synthetic vitamin A is supposed as of all-trans form, but vitamin $A$ in synthetic vitamin $A$ oil is not all all-trans vitamin A. As it is important to know the values obtained by the methods actually used in the commercial transactions, a comparison of the values obtained by the method in the 16 th edition of U. S. Pharmacopeia, Carr-Price method and the maleic value method was performed. When the relative bio-potency caluculated from the maleic value is higher than $85 \%$, the value obtained by the U. S. Pharm. method is practically equal to the true potency and in the author's biotests the value obtained by the spectrophotometry is considered to show the true potency when the relative bio-potency obtained from the maleic value is $78 \%$. This result concurs with that of Murray et ${ }^{5}$ ) that the value obtained spectrophotometrically shows the true bio-potency of the general fish liver oil and differs from the result of Ames et al.

It is also interesting that the relative bio-potency of vitamin $A$ in the undistilled oil extracted from fresh liver was very high almost equal to that of all-trans vitamin $A$. The existence of the marked isomerisation of vitamin A even in the undistilled oil in the previous paper is considered that the isomerisation has already occured in the liver sample. From this fact, to get the vitamin A of high relative bio-potency from fish liver, it is necessary to use the fresh liver and to prevent the isomerisation during the extraction as well as to consider the conditions of heat treatments such as distillation. As some of vitamin $A$ in fish liver oils, especially in the distilled oil samples have the relatively lower bio-potencies, the cause of the isomerisation of vitamin $A$ in fish liver oil will be investigated and reported later.

I express my gratitude to Miss Kimiko Okazaki who helped me in these experiment. I also show my appreciation here to the Japan Fish Liver Oil Manufacturer's Association, Japan Aquatic Oil Association and the Vitamin Oil Technical Conference which co-operated in this study.

\section{Summary}

The vitamin A potency of fish liver oil was determined by the growth tests and the liver storage tests of albino rats, and the relationship between the maleic value and the bio-potency 
was confirmed.

Even in the lower level of the needed dose, the difference between the synthetic vitamin A oil and the fish liver oil was not occured in the non deficient period.

In the feeding level, the vitamin A potency of fish liver oil was shown better than that of the synthetic vitamin A oil by their growth effects.

By the comparison of the values obtained by various methods, the relationship between the vitamin A potency to all-trans vitamin A and the value obtained by spectrophotometry was discussed.

By the corrected equation obtained from the bio-tests in this report, the vitamin A potency estimated by the maleic value was about $10 \%$ higher than that obtained by the original method, and the vitamin A potency of fish liver oil having more than $78 \%$ of relative bio-potency was equal to that obtained by the spectrophotometry.

\section{References}

1) Haruo Baba: Japan. J. Nutr. 19, 137 (1961)

2) Ryohei Takada, Goichiro Katsui, and Michiko Fukano: Vitamin (Japan) 7, 662 (1954)

3) Ames, S. R., W. I. Swanson and K. W. Lehman: J. Am. Pharm. Ass. 49, 366 (1960)

4) Embree, N. D., S. R. Ames, R. E. Lehman and P. L. Harris:Method of Biochemical Analysis 4, 59, Interscience Pub. (1957)

5) Murray, T. K., and Campbell, J. A. : Fed. Proc. 20, 453 (1961)

\section{魚肝油ビタミンA の効カとしろねずみに対する成長効果 (要旨)}

\section{馬場 春夫(国立栄湌研究所)}

前報に示したとおり, 魚鯨肝油ビタミン $\mathrm{A}$ の生物効力は試料によつて種々の值を示し, 効力の大なものは全 トランス型ビタミン $\mathrm{A}$ に匹敵するが，なかには相対生物效力にして70\%を示すものもみられた。このような 異同はマレイン価から推定しえたように, 種々の条件によつて生ずる異性化によると考元られ，このような異 性化は合成ビタミンAについても観察された。それらの結果はしろねずみの成長試験においても認められた が，その投与量によつて差異を生ずるような傾向がみられたこと，既往の実験值法合成 $\mathrm{A}$ と天然 $\mathrm{A}$ と効力が 投与量の高い所で比較され，且つ差異を生じていないととから、マレイン価と生物効力の関係をたしかめ, 飼 料レベルに近い投与量でのビタミン A 效力の比較を行つた。又相対生物効力によつてビタミン A の効力を示す 場合, これは全トランス型ビタミン Aの効力に対する\%で表わされるので, 種々得られた值を用いて, 一般測 定に用いられる吸光法による測定值との比較検討を行つた。

以上の結果より, 限界投与量においても, 非欠乏動物では合成ビタミンA油, 天然ビタミンA油のビタミン $\mathrm{A}$ の生長効力に差を生じないこと, 充分量の投与ではむしろ, 天然A油がまさるとと, マレイン価から推定し た効力は, Ames らの值より10\%程度大きいとと, 相対生物効力 $78 \%$ 以上の魚肝油のビタミン A 值は吸光分析 值と一致するとと学みた。 